\title{
Radiocarbon in Corals:
}

Records of the Carbon Cycle, Surface Circulation and Climate

\author{
Ellen R.M. Druffel \\ University of California at Irvine. Irvine, California USA
}

\begin{abstract}
For more than two decades, coral skeletons have been used to reconstruct records of isotopic and chemical ratios in surface seawater (for reviews, see Druffel, 1997a; Gagan et al., 2000). Here I
\end{abstract} demonstrate how high precision ${ }^{14} \mathrm{C}$ records $( \pm 3)$ reveal information regarding regional mixing of surface and subsurface waters. Climatic variability on many time scales (e.g. El Niño, Pacific Decadal Oscillation, and the North Atlantic Oscillation) are detected in the corals by small changes in $\Delta{ }^{14} \mathrm{C}$. Radiocarbon records in corals have also been used to reconstruct the input of fossil fuel $\mathrm{CO}_{2}$ into the subtropical and tropical regions of the Pacific and Atlantic Oceans.

\section{Introduction}

Time histories of $\Delta^{14} \mathrm{C}$ (per mil, \%o, deviation of the ${ }^{14} \mathrm{C} /{ }^{12} \mathrm{C}$ ratio between a sample and that of a $19^{\text {th }}$ century wood standard) in corals vary on interannual to decade timescales because of changes in physical mechanisms such as vertical mixing and advection of upper ocean waters. Radiocarbon $\left(\Delta^{14} \mathrm{C}\right)$ in non-polar surface seawater is $40-80 \%$ o lower than that in the atmosphere because of upward mixing of subsurface waters that contain less ${ }^{14} \mathrm{C}$ due to radioactive decay during isolation from the atmosphere where ${ }^{14} \mathrm{C}$ is produced. Surface ocean $\Delta^{14} \mathrm{C}$ has also varied due to two human activities: 1) since 1880, burning of fossil fuels has produced ${ }^{14} \mathrm{C}$-free $\mathrm{CO}_{2}$ which has diluted atmospheric concentrations, and 2) production of bomb ${ }^{14} \mathrm{C}$ in the stratosphere in the late 1950s and early 1960s has caused ${ }^{14} \mathrm{C}$ levels in the atmosphere and ocean to rise. I present interannual to decadal scale variability of $\Delta^{14} \mathrm{C}$ in the surface ocean that reveal unique records of ocean circulation and carbon cycle dynamics.

Annual density bands are present in the calcium carbonate (aragonite) skeletons of most species of hermatypic corals. Upon X-radiographic analysis of a thin slab of coral (0.3-0.7 cm thick), alternating dense and

less dense bands are revealed, where one band pair represents one year's growth at most locations. Because aragonite is saturated in the surface ocean, it does not dissolve. Coralline aragonite retains a permanent record of the ${ }^{14} \mathrm{C} /{ }^{12} \mathrm{C}$ ratios, along with other chemical and isotopic signatures in the surface waters when the aragonite is incorporated into the coral skeleton.

A map of the coral locations in the Pacific and Atlantic Oceans is shown in Figure 1. The Pacific locations are Ponape $\left(7^{\circ} \mathrm{N}\right.$; Konishi et al., 1982), Hawaii $\left(19^{\circ} \mathrm{N}\right.$; Druffel et al., 2001), Abraham Reef (22 ${ }^{\circ}$; Druffel and Griffin, $1993)$, Fanning $\left(4^{\circ} \mathrm{N}\right)$, French Frigate Shoals $\left(24^{\circ} \mathrm{N}\right)$,

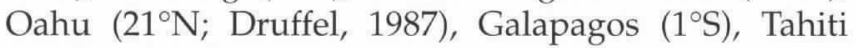
$\left(18^{\circ} \mathrm{S}\right.$; Druffel, 1981$)$, Fiji $\left(18^{\circ} \mathrm{S}\right)$ and Tarawa $\left(1^{\circ} \mathrm{N}\right.$; Toggweiler et al., 1991). The Atlantic coral locations are Bermuda $\left(32^{\circ} \mathrm{N}\right)$, Florida $\left(24^{\circ} \mathrm{N}\right.$; Druffel, 1997b; Druffel, 1989), Cape Verde Islands (17 N), Porto de Galinhas Brazil $\left(8^{\circ} \mathrm{S}\right)$ and Parcel dos Abrolhos Brazil (18º; Druffel, 1996).

\section{Circulation Records}

Pre-bomb $\Delta^{14} C$ Records (A.D. 1880-1955)

Pre-bomb $\Delta^{14} \mathrm{C}$ values were higher in the subtropical North (Hawaii) and South (Abraham Reef) Pacific than those in the tropical (Galapagos, Fanning) Pacific (Figure $2 \mathrm{a})$. Subtropical sites $\left(15^{\circ}-35^{\circ}\right)$ have relatively high pre-bomb $\Delta^{14} \mathrm{C}$ values ( $-40 \%$ o to $-55 \%$ ), whereas those sites nearer the equator are lower because of equatorial upwelling (e.g. Galapagos where values are $-80 \%$ to $-65 \%$ ). This pattern is due to downwelling and lateral advection that dominates subtropical gyre regions, whereas upwelling of ${ }^{14} \mathrm{C}$ depleted waters occurs in the equatorial zones. Subtropical sites in the Atlantic also average $-40 \%$ to $-55 \%$, though there are a few values $>$ A.D. 1940 that are lower, probably because of the Suess Effect (see below). In contrast, $\Delta^{14} \mathrm{C}$ values at Fiji and Fanning (Figure 2a) seem to oscillate 


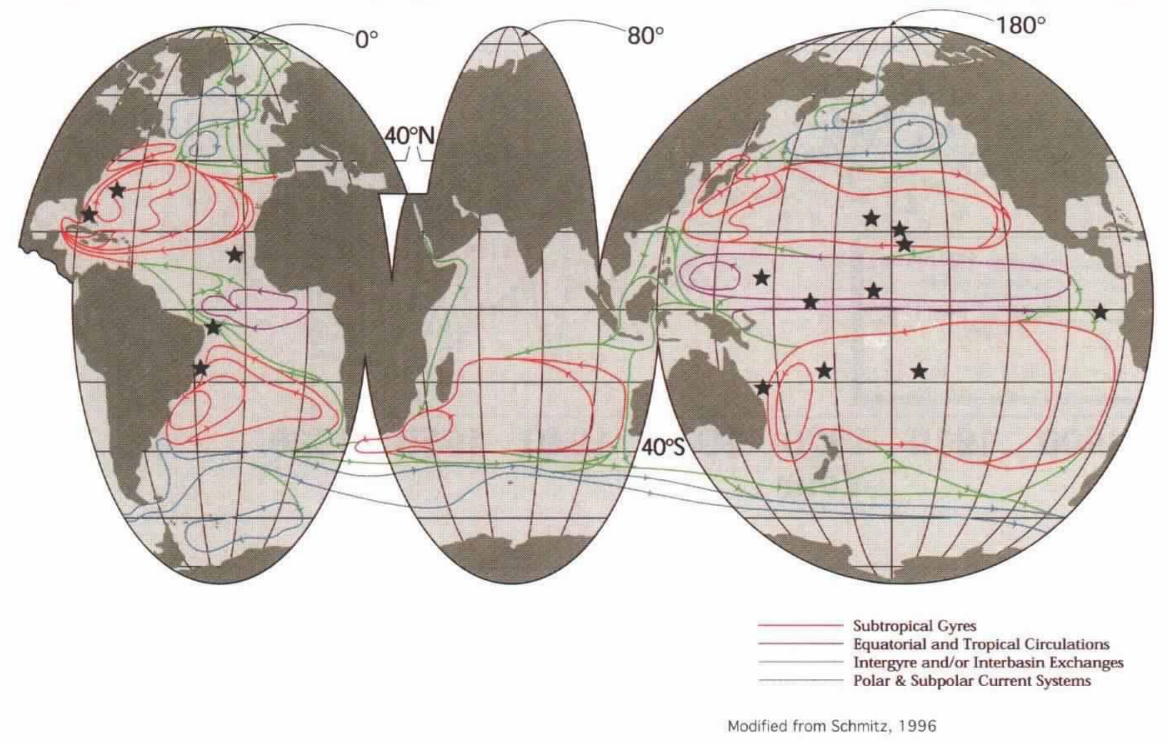

Figure 1. Map of surface currents in the world ocean and the coral locations used in this study (after Schmitz, 1996). The locations (and citations) in the Pacific are: French Frigate Shoals $\left(24^{\circ} \mathrm{N}\right)$, Oahu $\left(21^{\circ} \mathrm{N}\right.$; Druffel, 1987), Hawaii $\left(19^{\circ} \mathrm{N}\right.$; Druffel et al., 2001), Ponape ( $7^{\circ} \mathrm{N}$; Konishi et al., 1982), Fanning ( $4^{\circ} \mathrm{N}$; Druffel, 1987), Galapagos (1요 ; Druffel, 1981), Tarawa $\left(2^{\circ} \mathrm{N}\right)$, Fiji $\left(18^{\circ} \mathrm{S}\right.$; Toggweiler et al., 1991) and Abraham Reef (22 ${ }^{\circ}$; Druffel and Griffin, 1999; Druffel and Griffin, 1993). The locations (and citations) in the Atlantic are: Florida $\left(24^{\circ} \mathrm{N}\right)$, Bermuda $\left(32^{\circ} \mathrm{N}\right.$; Druffel, 1997), Cape Verde Islands $\left(17^{\circ} \mathrm{N}\right)$, and Porto de Galinhas ( $\left.8^{\circ} \mathrm{S}\right)$ and Parcel dos Abrolhos (18º S), both off the Brazilian coast (Druffel, 1996).

Frigate Shoals $\left(24^{\circ} \mathrm{N}\right)$ and Oahu $\left(21^{\circ} \mathrm{N}\right)$ corals which have the highest $\Delta^{14} \mathrm{C}$ values in the Pacific; these records reached values of $188-189 \%$ and 155-162\%o, respectively, by the early-1970s. The group with the second highest $\Delta^{14} \mathrm{C}$ values is found in corals from the south (Fiji, Abraham, Tahiti) and the western tropical (Ponape) Pacific; they have $\Delta^{14} \mathrm{C}$ values of $120-135 \%$ by the mid1970s and most stay high through 1980 (Abraham through 1990). The group with the third highest values is from the tropical Pacific (Fanning and Tarawa) where $\Delta^{14} \mathrm{C}$ results are $55-85 \%$ by the early 1970s; they are still rising in 1980. The lowest $\Delta^{14} \mathrm{C}$ values are found at the Galapagos Islands positioned in the Peru Current, which is the center of intense upwelling in the equatorial East Pacific. These values are only $20-40 \%$ in the early 1970s, and are still rising in 1987 (98\%o).

Post-bomb $\Delta^{14} \mathrm{C}$ values in the surface Atlantic corals also fall

between levels characteristic of the subtropics and levels closer to those at the Galapagos region. This would seem to be very significant oceanographically.

The $\Delta^{14} \mathrm{C}$ record at Abraham Reef extends back (for biennial samples) to A.D. 1635 (Druffel and Griffin, 1993). Increased decadal variability of $\Delta^{14} \mathrm{C}$ (range $25 \%$ ) was observed between A.D. 1680 and 1730 . This is thought to have been caused by changes in vertical mixing and/or changes in the relative transport of high $\Delta^{14} \mathrm{C}$ waters in the Eastern Australian Current and low $\Delta^{14} \mathrm{C}$ waters in the South Equatorial Current. These data also show century timescale changes in the periodicity of interannual variability (Druffel and Griffin, 1993).

During the last century, the range of subtropical Pacific pre-bomb $\Delta^{14} \mathrm{C}$ values (15\%, Fig 2a) is half that in the North Atlantic ( $30 \%$, Fig. 2b). This is because convective overturning between surface and subsurface waters occurs every winter during the formation of $18^{\circ} \mathrm{C}$ mode water in the North Atlantic (Druffel, 1989). This brings water with low $\Delta^{14} \mathrm{C}$ values from as deep as $400 \mathrm{~m}$ up to the surface in the Atlantic. No similar convective mixing occurs in the North Pacific; instead, the depth of the mixed layer (20 to $100 \mathrm{~m}$ ) depends on seasonal winds (Druffel et al, 2001).

\section{Postbomb $\Delta^{14}$ C Records (>A.D. 1950)}

A prominent feature of the post-bomb $\Delta^{14} \mathrm{C}$ time histories in the Pacific (Figure $3 a$ ) is the grouping into distinct ranges of results after 1960. The first is French into groupings dependent on circulation features, though the spread of $\Delta^{14} \mathrm{C}$ values is not as great as that in the Pacific. In the North Atlantic, values of $156 \%$ and $159 \%$ were reached at Florida and Bermuda in 1970 and 1974, respectively (Figure 3b). Values rose faster at Florida than at any other Atlantic location we studied for two reasons: 1 ) bomb ${ }^{14} \mathrm{C}$ was produced in the northern hemisphere and admitted to the southern hemisphere air with a 1-2 year mixing time (Levin et al., 1985; Nydal and Lovseth, 1983); and 2) Gulf Stream waters (that lave the Florida coral) mix horizontally, therefore $\Delta^{14} \mathrm{C}$ rises more quickly in these waters because of longer exposure to atmospheric bomb ${ }^{14} \mathrm{CO}_{2}$. In contrast, the Bermuda coral achieves a maximum $\Delta^{14} \mathrm{C}$ value several years later than the Florida record, because surface ${ }^{14} \mathrm{C}$ in the Sargasso Sea is diluted by low $\Delta^{14} \mathrm{C}$ subsurface waters during $18^{\circ} \mathrm{C}$-mode water formation in late winter (Druffel, 1989). The Brazilian coral records show a steady rise of $\Delta^{14} \mathrm{C}$ after 1957 , with an initial leveling off in 1960-1961. Between 1962 and 1968 , the long Brazilian $\left(18^{\circ} \mathrm{S}\right)$ record shows a large, steady rise of $\Delta^{14} \mathrm{C}$ values, then a slower rise to 1974 when the highest value of $138 \%$ is attained. Interestingly, the Cape Verde record levels off in the late 1960s.

The groupings of bomb $\Delta^{14} \mathrm{C}$ records based on circulation features within each ocean indicate that ${ }^{14} \mathrm{C}$ is primarily a tracer of ocean circulation. The only time that $\Delta^{14} \mathrm{C}$ was significantly affected by gas exchange 

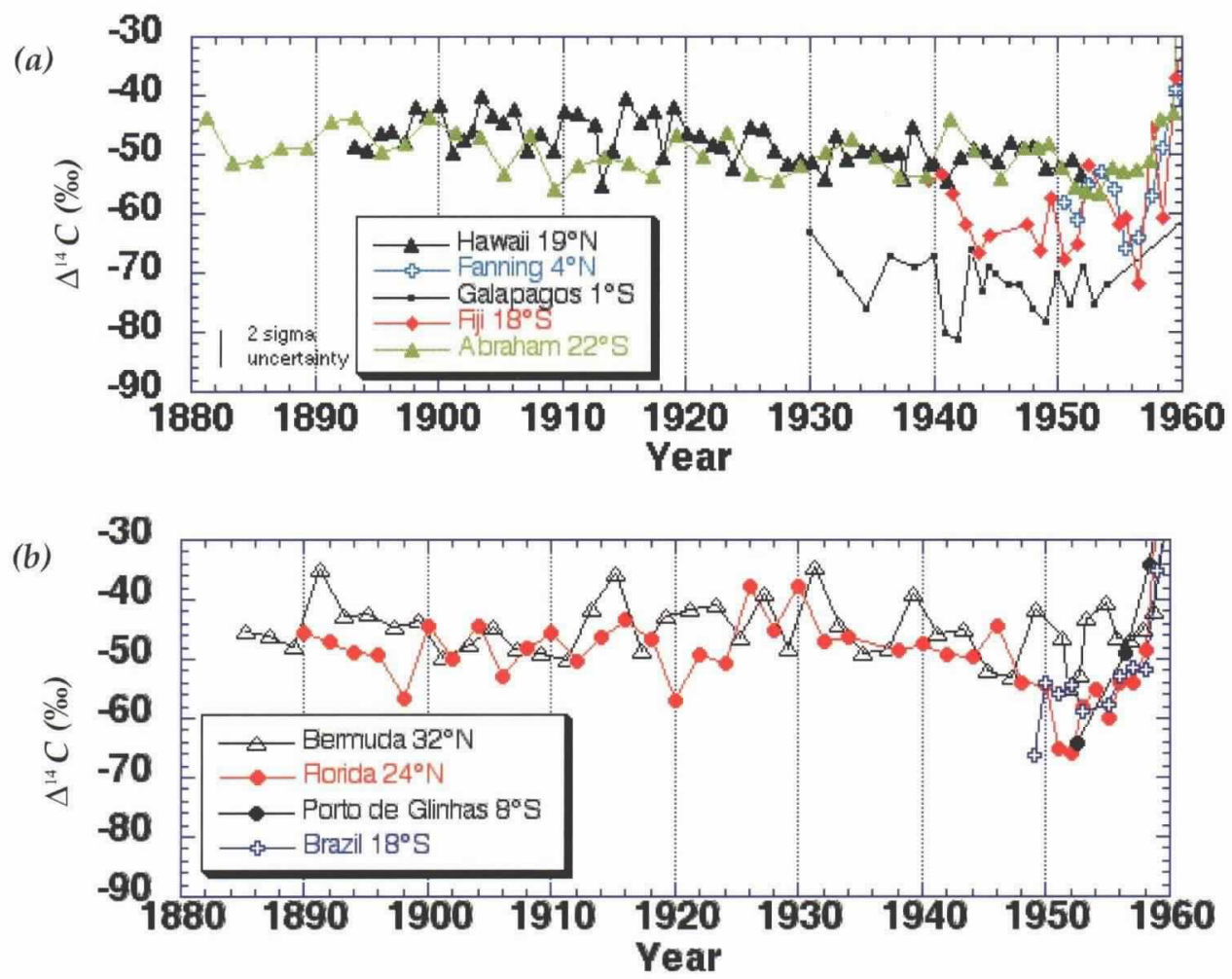

Figure 2. a) Prebomb coral $\Delta^{14} \mathrm{C}$ values for annual and biennial coral bands from the Pacific (as cited in Figure 1); and b) Prebomb $\Delta^{14} \mathrm{C}$ values for annual and biennial coral bands from the Atlantic (as cited in Figure 1).

with the atmosphere was during the 1960s when the atmosphere-ocean gradient in $\Delta^{14} \mathrm{C}$ was at a maximum. Additionally, the Suess Effect is measurable and has grown to significant proportions during the 1980s and 1990s.

Subtropical sites such as French Frigate Shoals display more rapid increases in $\Delta^{14} \mathrm{C}$ than those continually diluted by equatorial upwelling, such as Fanning, Tarawa and Galapagos. After 1974, $\Delta^{14} \mathrm{C}$ values decrease noticeably at most subtropical regions and continue to rise at Fanning, Tarawa and Galapagos. This is due to upwelling of bomb ${ }^{14} \mathrm{C}$-laden waters near the equator, which enter the subtropical gyres via downwelling and circulate toward the equator on the order of 6-10 years after the initial input of the bomb ${ }^{14} \mathrm{C}$ transient (Quay et al., 1983). The slopes of the postbomb Atlantic $\Delta^{14} \mathrm{C}$ records between 1962 and 1965, the most sensitive part of the ${ }^{14} \mathrm{C}$ rise, revealed that Porto de Galinhas $\left(8^{\circ} \mathrm{S}\right)$ and Cape Verde Islands $\left(17^{\circ} \mathrm{N}\right)$ appear to have been diluted the most by subsurface water due to upwelling in the South Equatorial Current and the North Equatorial Current (Druffel, 1996).

\section{The Carbon Cycle}

The Suess Effect

The decrease of $\Delta^{14} \mathrm{C}$ in atmospheric $\mathrm{CO}_{2}$ during the first half of the $20^{\text {th }}$ century is known as the Suess Effect
(Suess, 1953). It is attributed mainly to the input of ${ }^{14} \mathrm{C}$ free $\mathrm{CO}_{2}$ to the atmosphere from the burning of fossil fuels, and subsequent transfer into the ocean by gas exchange. There are five corals whose $\Delta^{14} \mathrm{C}$ records are long enough to assess the oceanic Suess Effect: Hawaii (7 $\pm 3 \%$; Druffel et al., 2001), Florida (11 $\pm 3 \%$; Druffel, $1997 b)$, the Galapagos (6 $\pm 5 \%$; Druffel, 1981) and Abraham Reef and Heron Island in the Great Barrier Reef $(4 \pm 3 \%$ and $2 \pm 3 \%$, respectively; Druffel and Griffin, 1993, 1999). The northern subtropical locations (Hawaii and Florida) show a Suess Effect that agrees with that calculated for a mid-gyre region using a box diffusion model ( 10\%; Stuiver and Quay, 1981). The unusually small Suess Effect in the southwestern Pacific Ocean (Great Barrier Reef) may be linked to non-steady state mixing in this area. Also, there was no correlation between El Niño events and low ${ }^{14} \mathrm{C}$ during 1880-1925 (as there had been before and after this period). These factors may have caused $\Delta^{14} \mathrm{C}$ to have been low during the turn of the $20^{\text {th }}$ century and as a result masked the Suess Effect at this location (Druffel and Griffin, 1999). There seems to be a large scale, low frequency event that is driving this variability.

As the bomb ${ }^{14} \mathrm{C}$ transient decreases in the atmosphere and penetrates deeper into the ocean, the Suess Effect is increasing with time. Values as high as $30 \%$ to $40 \%$ are expected in the surface ocean by 2002 , because of increasing levels of fossil fuel $\mathrm{CO}_{2}$ in the atmosphere. 


\section{Climate Signals}

In general, the ocean is not at steady state on interannual or decadal timescales with respect to climatically important surface properties, such as sea surface temperature (SST; Chao et al., 2000). Inter-annual variability is apparent in all of the pre-bomb $\Delta^{14} \mathrm{C}$ records, with changes ranging from $5-30 \%$ every few years (Figures 2a and b). Two physical mechanisms that can result in variable $\Delta^{14} \mathrm{C}$ are: 1 ) changes in vertical mixing within the current that laves the coral site, and 2) changes in the source(s) of the laterally advected water mass(es). For example, the Hawaii coral $\Delta^{14} \mathrm{C}$ data show a direct correlation with local and Northern Pacific SST (Druffel et al., 2001), indicating that vertical mixing of waters near Hawaii and in the North Pacific gyre as a whole is the likely

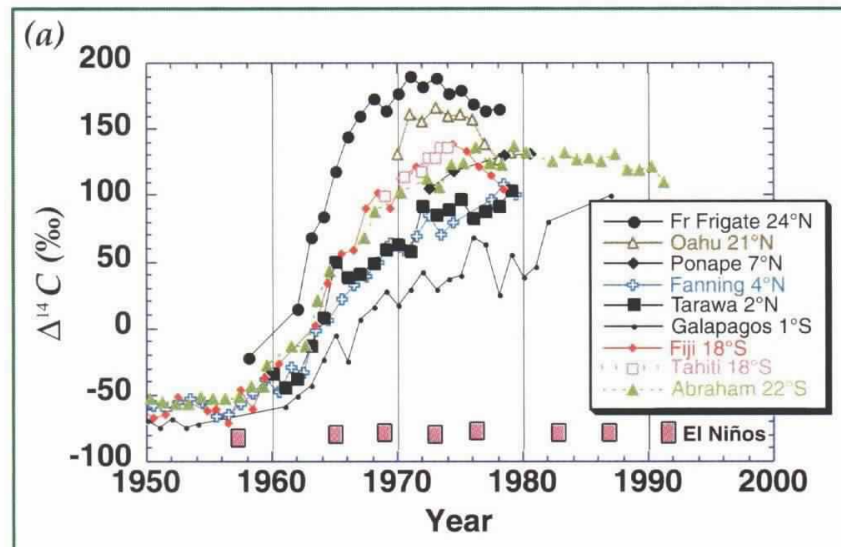

(b)

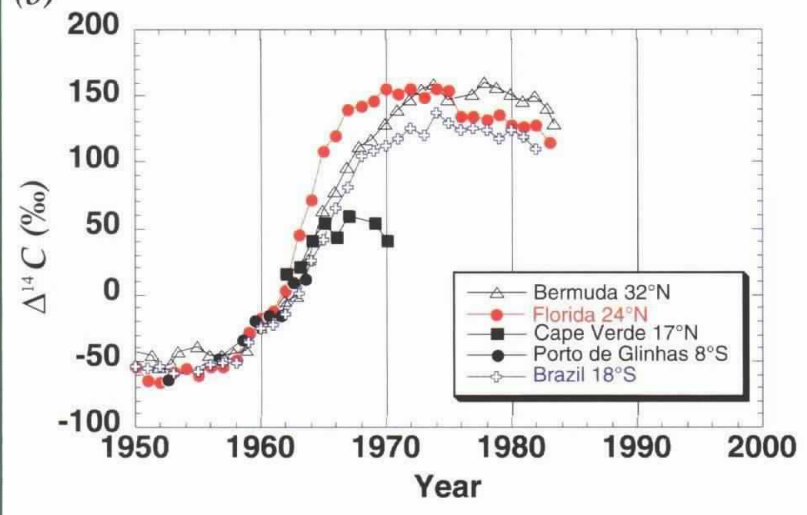

Figure 3. a) Postbomb coral $\Delta^{14} \mathrm{C}$ values for annual coral bands from the Pacific (as cited in Figure 1 caption); and b) Postbomb $\Delta^{14} \mathrm{C}$ values for annual coral bands from the Atlantic (as cited in Figure 1 caption). The 1987 Galapagos result is for a surface seawater DIC sample (WHA\#32, = 98\%o) collected in February 1987 by Mitchell Colgan. physical mechanism to cause variable $\Delta^{14} \mathrm{C}$. Cross spectral analyses reveals that the 6 year period is coherent between the prebomb $\Delta^{14} \mathrm{C}$ record at Hawaii and wind speed records at Hawaii (COADS; Druffel et al., 2001). These results suggest that the dynamics of climatic forcing in the North Pacific correlates with $\Delta^{14} \mathrm{C}$ in the surface.

\section{El Niño}

Interannual variability of climate known as ENSO (El Niño/Southern Oscillation) is caused by complicated interactions of the tropical ocean and atmosphere. The $\Delta^{14} \mathrm{C}$ values of surface ocean DIC during post-bomb El Niño events vary with location in the Pacific. $\Delta^{14} \mathrm{C}$ values were higher than normal during most El Niño events (1957-58, 1965, 1969, 1972-73, 1976, 1982-82, 1986-87) in corals from the Galapagos, Fanning, Tarawa, and Fiji (Figure 3a). Low $\Delta^{14} \mathrm{C}$ values were found during some El Niño events in corals from Abraham Reef, because of the southerly displacement of low- $\Delta{ }^{14} \mathrm{C}$ waters into the southern Great Barrier Reef region (Druffel and Griffin, 1993, 1999). There was no obvious correlation between $\Delta^{14} \mathrm{C}$ at the North subtropical Pacific sites and the El Niño events, which is expected from the non-correlation between El Niño records and SST in the subtropical North Pacific.

\section{Pacific Decadal Oscillation}

Decadal shifts of climate centered in the North and tropical Pacific are known as the Pacific Decadal Oscillation (PDO; Mantua et al., 1997). For example, the Pacific climatic shift of 1976 was a well documented, decadal warming of tropical waters (Gu and Philander, 1995). Guilderson and Schrag (1998) showed that there was an abrupt increase in the $\Delta^{14} \mathrm{C}$ values of a Galapagos coral during the upwelling season after the 1976 El Niño. Hypotheses as to the source(s) of decadal climate changes are ocean-atmosphere coupled instability in the subtropics (Latif and Barnett, 1994) and exchanges of subtropical and tropical subsurface waters that cause changes to the ocean-atmosphere interactions in the tropics ( $\mathrm{Gu}$ and Philander, 1997). Global warming has also been suspected of causing more frequent and more severe El Niño events since the 1976 climate shift in the Pacific (Trenberth and Hoar, 1997). Lysne et al. (1997) use an ocean general circulation model to suggest that the extratropical regions of the North Pacific can generate decadal variability of SST on the equator between 1968 and 1984, that precedes the effect at the tropics by $4-5$ years. Whether the tropical Pacific index lagged the subtropical N Pacific index, or vice-versa, prior to 1968 has not been established because of incomplete data records at both locations.

Likewise, the effect of decadal mixing changes on the climatic variability in the upper ocean is not 
known, because there are too few observations. It is important to define the decadal shift in the oceanic mean state, especially for predicting the climate variability in the temperate and tropical ocean. Bomb-produced tracers such as ${ }^{14} \mathrm{C}$ and ${ }^{3} \mathrm{H}$ are particularly useful for examining decadal timescale variability of ocean mixing, because their input to the ocean was several decades ago, and their signals are far above natural levels.

\section{North Atlantic Oscillation (NAO)}

The NAO is the difference in winter sea-level air pressures between the high at Lisbon, Portugal, and the low at Stykkisholmur, Iceland. It displays decadal shifts that are linked to changing wind patterns over the North Atlantic (Hurrell, 1995).

A cross spectral analysis of NAO values and annual water mass renewal rate records for the North Atlantic obtained from $\Delta^{17} \mathrm{C}$ and a multibox isopycnal mixing model from Florida and Bermuda corals (Druffel, 1997b) reveals that the 6year period is coherent ( $95 \%$ confidence level) between 1885 and 1955. Also, decadal time scale decreases of the winter SST anomaly east of Newfoundland (Deser and Blackmon, 1993) match the pulses of high water mass renewal rate in the North Atlantic (Druffel, 1997b). A cross spectral analysis of these two records (between 1902 and 1953) reveals that the 9-year period is also coherent (the SST anomaly lags water mass renewal rate by 2 years). Thus the link between ocean circulation (SST and $\Delta^{14} \mathrm{C}$ ) and climate (NAO) is demonstrated for the North Atlantic. Future studies will reveal if other ocean basins are similarly linked.

\section{Synthesis}

Surface radiocarbon responds to vertical and horizontal changes in near surface circulation. Changes in vertical mixing alter the relative amounts of ${ }^{14} \mathrm{C}$-poor water admitted from the subsurface into the mixed layer. Should this change persist on time scales greater than one year, interannual and longer time scale variability of $\Delta^{14} \mathrm{C}$ appears, much like the temporal differences seen in the prebomb $\Delta^{14} \mathrm{C}$ records from the subtropics (Figures $2 \mathrm{a}$ and $\mathrm{b}$ ). If SSTs (or chemical recorders of SST such as Sr/Ca) are colder when $\Delta^{1+} \mathrm{C}$ is lower and if SSTs are warmer when $\Delta^{14} \mathrm{C}$ is higher, as in the Hawaii corals (Druffel et al., 2001), then vertical mixing is the primary control on $\Delta^{14} \mathrm{C}$ at this site. Alternatively, if $\Delta^{1+} \mathrm{C}$ and SST (or wind speed, another local climatic factor) are not correlated, then it is likely that a change in local or remote circulation is the dominant control of $\Delta^{14} \mathrm{C}$. Higher variability of $\Delta^{14} \mathrm{C}$ from A.D.1680-1730 at Abraham Reef is an example of increased variability of East Australian Current and
South Equatorial Current water masses advecting into the Coral Sea during the Little Ice Age (Druffel and Griffin, 1993, 1999).

Longer time scale variability in climate, such as the PDO and NAO, are documented for only the past 50-100 years. Investigators have recognized variability of ocean circulation on many time scales. A 15 to 20-year period has been identified for SST in the Pacific over the past century (Chao et al., 2000). A 6-year period dominates the annual $\Delta^{14} \mathrm{C}$ records of Hawaii and Bermuda coral (Druffel et al, 2001; Druffel and Griffin, 1993). The 15 and 25-year periods dominate the Abraham Reef biennial coral $\Delta^{14} \mathrm{C}$ record for 1635-1797 and 1798-1953, respectively. Radiocarbon in corals, in conjunction with $\mathrm{Sr} / \mathrm{Ca}$ ratios, promises to reveal several-century records of these climatic phenomena and their relationships with changes in ocean circulation and the carbon cycle. The examples given here are only the beginning of such an effort. Also, monthly resolution sampling of corals yield important information about the timing of events on a shorter than one year timescale (Guilderson and Schrag, 1998).

Implications for the carbon cycle are found within the $\Delta^{1+C}$ records. In view of the small Suess Effect in the southwestern Pacific corals, variability of oceanic uptake of atmospheric $\mathrm{CO}_{2}$ likely took place from 1870-1920. Alternatively, the expected Suess Effect of $10 \pm 3 \%$ o found in the Hawaiian and Florida corals implies that the uptake of excess $\mathrm{CO}_{2}$ was the same during the first half of the last century in these oceanic regions. More oceanic locations, in particular the South Atlantic, South central Pacific and the Indian Oceans, need to be studied in order to adequately map the input of fossil fuel $\mathrm{CO}_{2}$ to the oceans.

\section{Conclusions}

Spatial variability of $\Delta^{14} \mathrm{C}$ time series from the Atlantic and Pacific Oceans is attributed to differences both in advected currents and in degrees of vertical mixing. The $\Delta^{14} \mathrm{C}$ records of tropical corals rise slower than those in the mid-gyre, and keep rising long after the mid-gyre records decrease due to net transport of bombladen waters from the subtropics to the tropics. Climate changes, such as El Niño and the NAO, are recorded in coral $\Delta^{1+} \mathrm{C}$. One of the important future directions in this field is to construct several century-long records of $\Delta^{14} \mathrm{C}$ in corals. Determination of longer climate records for the eastern Indian Ocean, and the tropical and the South central Pacific are particularly important to deconvolve the teleconnections between climate and circulation in the large, virtually unmapped (with respect to ${ }^{14} \mathrm{C}$ ) regions of the world ocean. 


\section{Acknowledgements}

My thanks go to Sheila Griffin who produced most of the $\Delta^{14} \mathrm{C}$ measurements presented here at the La Jolla UCSD, WHOI and UCI Radiocarbon Laboratories. I also thank colleagues at LLNL Center for AMS Research for $\Delta^{1+} \mathrm{C}$ measurements of the Hawaiian coral. Reviews of the manuscript by J. Cole and J. R. Toggweiler were very helpful. This work was funded by NSF Chemical Oceanography Program grant no. OCE-9711326.

\section{References}

Chao Y., M. Ghil and J. McWilliams, 2000: Pacific Interdecadal variability in this century's sea surface temperatures. Geophys. Res. Lett. 27, 2261-2264.

Deser, C. and M. Blackmon, 1993: Surface climate variations over the North Atlantic Ocean during winter: 1900-1989. J. Climate, 6, 1743-1753.

Druffel, E.R.M., 1981: Radiocarbon in annual coral rings from the eastern tropical Pacific Ocean. Geophys. Res. Lett., 8, 59-62.

Druffel, E.R.M., 1987: Bomb radiocarbon in the Pacific: Annual and seasonal timescale variations. J. Mar. Chem., 45, 667-698.

Druffel, E.R.M., 1989: Decade time scale variability of ventilation in the North Atlantic determined from high precision measurements of bomb radiocarbon in banded corals. J. Geophys. Res., 94, 3271-3285.

Druffel, E.R.M., 1996: Post-bomb radiocarbon records of surface corals from the tropical Atlantic ocean. Radiocarbon, 38 (3), 563-572.

Druffel, E.R.M., 1997a: Geochemistry of corals: Proxies of past ocean chemistry, ocean circulation and climate. Proceedings of the National Academy of Sciences, 94, 8354-8361.

Druffel, E.R.M., 1997b: Pulses of rapid ventilation in the North Atlantic surface ocean during the last century. Science, 275, 1454-1457.

Druffel, E.R.M. and S. Griffin, 1993: Large variations of surface ocean radiocarbon: Evidence of circulation changes in the southwestern Pacific. J. Geophys. Res., 98, 20249-20259.

Druffel, E.R.M. and S. Griffin, 1999: Variability of surface ocean radiocarbon and stable isotopes in the southwestern Pacific. J. Geophys. Res., 104 (C10), 23607-23613.

Druffel, E.R.M., S. Griffin, M. Kashgarian, T. Guilderson, J. Southon and D. Schrag, 2001: Changes in subtropical North Pacific Radiocarbon precede climate variability in the tropical Pacific. Radiocarbon, 43(1):15-25.

Gagan, M.K., L.K. Ayliffe, J.W. Beck, J.E. Cole, E.R.M. Druffel, R.B.D. An and D.P. Schrag, 2000: New Views of Tropical Paleoclimates from Corals. Quaternary Science Reviews, 19, 45-64.

Gu, D. and S. Philander, 1995: Secular changes of annual and interannual variability in the tropics during the past century. J. Climate, 8, 864-876.

Guilderson, T. and D. Schrag, 1998: Abrupt shift in subsurface temperatures in the tropical Pacific associated with changes in El Niño. Science, 281, 240-243.

Hurrell, J., 1995: Decadal trends in the North Atlantic Oscillation: regional temperatures and precipitation. Science, 269, 676-679.

Konishi, K., T. Tanaka and M. Sakanoue, 1982: Secular variation of radiocarbon concentration in sea water: Sclerochronological approach, In: Proceedings of the Fourth International Coral Reef Symposium. Edited by E.D. Gomez, Marine Science Center, University of the Philippines, Manila.

Latif, M. and T. Barnett, 1994: Causes of decadal climate variability over the North Pacific and North America. Science, 266, 634-637.

Levin, I., B. Kromer, H. Schoch-Fischer, M. Bruns, M. Munnich, D. Berdaun, J.C. Vogel and K.O. Munnich, 1985: 25 years of tropospheric ${ }^{14} \mathrm{C}$ observations in Central Europe. Radiocarbon, 27 (1), 1-19.

Lysne, J., P. Chang and B. Giese, 1997: Impact of the extratropical Pacific on equatorial variability. Geophys. Rsch. Lett., 24 (21), 2589-2592.

Mantua, N., S. Hare, Y. Zhang, J. Wallace and R. Francil, 1997: A Pacific interdecadal climate oscillation with impacts on salmon production. Bulletin of the American Meteorological Society, 78, 1069-1079.

Nydal, R. and K. Lovseth, 1983: Tracing bomb ${ }^{14} \mathrm{C}$ in the atmosphere. J. Geophys. Res., 88, 3621-3646.

Quay, P., M. Stuiver and W. Broecker, 1983: Upwelling rates for the equatorial Pacific Ocean derived from the bomb ${ }^{14} \mathrm{C}$ distribution. J. Mar. Res., 41, 769-792.

Schmitz W.J., 1996: On the World Ocean Circulation: Volume 1: Some Global Features/North Atlantic Circulation. Woods Hole Oceanographic Institution, Technical Report WHOI-96-03.

Stuiver M. and P. Quay, 1981: Atmospheric ${ }^{14} \mathrm{C}$ changes resulting from fossil fuel $\mathrm{CO}_{2}$ release and cosmic ray flux variability. Earth and Planetary Science Letters, 53, 349-362.

Suess, H.E., 1953: Natural radiocarbon and the rate of exchange of carbon dioxide between the atmosphere and the sea, In: Proceedings Conference Nuclear Processes in Geological Settings. University of Chicago Press, Chicago, pp. 52-56.

Toggweiler, J.R., K. Dixon and W.S. Broecker, 1991: The Peru Upwelling and the ventilation of the South Pacific thermocline, J. Geophys. Res., 96, 20, 467-20,497.

Trenberth, K. and T. Hoar, 1997: El Niño and climate change. Geophys. Res. Lett., 24, 3057-3060. 